RACAR : Revue d'art canadienne

Canadian Art Review

RACAR

\title{
A New Italian Painting for Vancouver: The Meeting of Venus and Adonis, by Luca Giordano
}

\section{George Knox}

Volume 15, numéro 1, 1988

URI : https://id.erudit.org/iderudit/1073446ar

DOI : https://doi.org/10.7202/1073446ar

Aller au sommaire du numéro

\section{Éditeur(s)}

UAAC-AAUC (University Art Association of Canada | Association d'art des universités du Canada)

\section{ISSN}

0315-9906 (imprimé)

1918-4778 (numérique)

Découvrir la revue

\section{Citer ce document}

Knox, G. (1988). A New Italian Painting for Vancouver: The Meeting of Venus and Adonis, by Luca Giordano. RACAR : Revue d'art canadienne / Canadian Art Review, 15(1), 85-86. https://doi.org/10.7202/1073446ar

Tous droits réservés (C) UAAC-AAUC (University Art Association of Canada | Association d'art des universités du Canada), 1988
Ce document est protégé par la loi sur le droit d'auteur. L'utilisation des services d'Érudit (y compris la reproduction) est assujettie à sa politique d'utilisation que vous pouvez consulter en ligne.

https://apropos.erudit.org/fr/usagers/politique-dutilisation/ 
Please note that in the second issue of 1988 there will be a complete updated list of all major acquisitions by Canadian museums and galleries during the past two years.

\section{A New Italian Painting for Vancouver: The Meeting of Venus and Adonis, by Luca Giordano}

GEORGE KNOX

University of British Columbia

The Vancouver Art Gallery has recently acquired an important painting by Luca Giordano (Naples 1634-1705 Naples). The Meeting of Venus and Adonis (Cover) is painted in oil on canvas, $205 \times 155 \mathrm{~cm}$., and is signed at the centre on the rock: Jordan(us) F. Nothing is known of its history prior to its appearance in Christie's sale, London, 24 October 1986, as lot 97 .

Luca Giordano enjoyed a dazzling career throughout the second half of the seventeenth century. During this period, he was certainly the leading painter in Naples, and it could be claimed that he was not merely the leading painter in Italy at this time, but in the whole of Europe. He painted vast and celebrated works for the Medici in Florence between 1682 and 1685 and for Charles II of Spain in the Escorial and at Buen Retiro between 1692 and 1702.'

In 1652-53, at the age of eighteen, he made his first visit to Venice, and his first important commissions were for the Venetian churches of San Pietro di Castello, Santa Maria de Pianto and Santo Spirito. At this time, he was deeply impressed by Venetian painting of the sixteenth century, and there is every probability that the present picture was painted at this crucial moment in his career under the impact of his initial experience there.

1 The Basic account of Giordano remains: Oreste Ferrari \& Giuseppe Scavizzi, Luca Giordano, 3 vols (Naples, 1966). See also the entries by Oreste Ferrari in the exhibition catalogue, Painting in Naples from Caravaggio to Giordano (Washington, 1983), 168-180.
The painting is very strongly Venetian in character, with the predominant influence of Tintoretto.

The subject of the picture is of quite unusual interest. In the Christie's sale catalogue, it was listed as Diana and Actaeon, an identification that immediately presented problems. In fact, it is a complete visualization of the account of the meeting of Venus and Adonis as it is described in (anto) III of the Adone of the Cavaliere Marino. Giambattista Marino (Naples 1569-1625 Naples) was the most celebrated poet of his day in Italy and throughout Europe, and his most famous work, the Adone (Adonis), an enormously long poem running to 41,000 verses, was first published in Paris in 1623, with a dedication to Catherine de Medici. In Stanzas 61-122 of Canto III, Marino describes how Venus decides to disguise herself as Diana before encountering Adonis, and this accounts for the crescent moon on her brow:

D'argento in fronte immacolata e bianco vedesi scintellar I una lucentc. (Adone III, 63, 3-4²)

Thus disguised, she is the image of chastity:

Tal ch'ai cani, agli stali, al corno, al'asta la più lasciva Dea par la più casta.

(Adone III, 63, 6-3)

But the disguise has other advantages. The satyr, in the shadows on the right, is suggested by a

2 Giambattista Marino, Adone, ed. Marzio Pieri, I (Bari, 1975), 167ff.; Marino, Adone, ed. Giovanni Pozzi (Milan, 1976), $158 \mathrm{ff}$. 
passage implying that if she is seen by some satyr in the wood, Pan will assume that it is his own Diana who is shameless: ${ }^{3}$

a Pan più tosto il referisca a dica,

ch'ancor Diana sua non e pudica

(Adone in, 64, 7-8)

As she hastens to meet Adonis, she wounds her foot on a rose, turning the white roses pink and red: she finds Adonis asleep, but when he awakens he stanches the wound with a cloth.

Cupid, who seems to be making off in the upper left corner, appears a little later in the text, as Adonis takes Venus's wounded foot in his hand:

Disce Amor, che non era indi lontano:

- Non voléa si bel piè men bella mano! -

(Adone III, 115, 7-8)

So the picture embraces most of the essentials of the story, and must be read as a tribute by the young Luca Giordano to the genius of his poet compatriot.

The discussion of the links between Marino's poetry and seventeenth-century painting has been largely confined to the problem of Marino's influence on Poussin. ${ }^{4}$ Bellori describes the friendship between the celebrated poet, at the height of his career in Paris, and the young unknown painter, drawing on the important series of drawings by the young Poussin, now at Windsor Castle, that he claims are illustrations for Marino's poems. ${ }^{5}$ One of these is referred to by Bellori as La tintura della rosa and is hence closely related to our painting. This, however, seems to illustrate a version of the story in which Venus wounds her foot while hunting with Adonis, as described in Marino's early poem La Rosa (first published in the Rime, Venice 1602), rather than the much more developed account of twenty years later in the Adone. ${ }^{6}$ The only painting by Poussin that can be

3 This is a reference to the old story of Pan and the wool, recounted by Virgil, Georgics, 111, 5-23, represented by Annibale Carracci in the Farnese ceiling, and celebrated by Robert Browning. For a full account, see Elizabeth McGrath, "Pan and the wool," Ringling Museum of Art Journal (1983), 52-69.

4 For Marino and his contemporaries, see Gerald Ackerman, "Giovanni Battista Marino's contrilution to seicento art," The Art Bulletin (1961), 326ff.; also the introduction to Giovanni Battista Marino, La Galleria, e cura di Marzio Pieri (Padua, 1979).

5 Giovanni Pietro Bellori, Le vite de' pittori, scultori et architetti moderni (Rome, 1672), 410-11: Jane Costello, "Poussin's drawing for Marino and the New Classicism: 1-Ovid's Metamorphoses," Journal of the Courtauld and Warburg Institutes, xviI (1955), 298.

6 Richard Spear, "The literary source of Poussin's Realm of Flora," Burlington Magazine, cvir (1965), 563ff.; Robert B. Simon, "Poussin, Marino, and the interpretation of mythology," The Art Bulletin, 60 (1978), 56-68. claimed to descend from a passage in the Adone is the famous Triumph of Venus at Philadelphia. So far as I know, no Italian painting of the seventeenth century has been shown to be inspired by the Adone, except a magnificent frieze painted with scenes from the story of Venus and and Adonis after Marino by Filippo Zanimberti (Brescia 1585-1636 Venice) that was once in the great room of Camera Loredan a San Stefano in Venice. Unfortunately this decoration, no doubt located in the great room occupying the full width of the façade that looks up the campo towards the church of San Stefano, has disappeared, but Ridolfi, in his brief life of Zanimberti, devotes a full page to it. ${ }^{7}$ It is possible that the fame of this work was a factor that led to the selection of the subject of our painting, and it is certain that throughout the seventeenth century Venice remained something of a centre for the cult of Marino, his works being frequently reprinted there.

Two self-portraits of Luca Giordano have come down to us, which show him to have been a very good-looking man. ${ }^{8}$ They also make it quite plain that for the Adonis in this picture he used himself as a model. Thus, we have here a third self-portrait of the artist as a young man at the age of eighteen or nineteen. To portray himself in this way may seem to us a little extravagant, but we must remember that Venus in Italy is not simply the goddess of love. She is the mother and protector of Aeneas, and under her aegis Rome was founded. To that extent, she is the ancestress of all Italians. The young Luca pays homage to the ancient presiding deity of his country.

As noted above, nothing is known of this picture prior to its appearance in Christic's sale of 24 October 1986, but a considerable number of canvases by Luca are recorded in the early inventories of Venetian palaces, without titles or any other means of identification. Our picture is very likely one of these.

7 Carlo Ridolfi, Le maraviglie dell'arte, II (Venice, 1648), 275; Fontana ed. Moretti (Venice, 1967), 9-10, indicates that it was on the staircase.

8 Of particular relevance is the one in the Galleria Nazionale in Rome, which has been dated c. 1659 (Ferrari \& Scavizzi [1966], 50, pl. 91). If the Adonis is acceptable as a sclfportrait, it would further confirm our dating of 1652-53. Gladys Wilson points out to me that a figure virtually the same as the Adonis may be observed in another carly canvas by Luca in the Musée Cantonal des Beaux-Arts in Lausanne, no. 1223, The Meeting of Jacob and Rachel, 176.5 $\times$ $231 \mathrm{~cm}$., signed: Jordanus F.: exhibited Geneva, Musée d'Art et d'Histoire, Art Vénitien en Suisse et au Lichtenstein (1978), 101

The University of British Columbia Vancouver, British Columbia V6R 2KI 